Kirja-arvio

\title{
Kulttuurikartoitusta ja musiikkia, kulttuuriperintöä ja käytännön toimintaa
}

\author{
Sweers, Britta ja Sarah M. Ross (toim.). 2020. Cultural Mapping and Musical \\ Diversity. Sheffield ja Bristol: Equinox Publishing Ltd. 321 sivua.
}

\author{
Heidi Henriikka Mäkelä
}

$\mathrm{V}$ iimeisinä vuosikymmeninä YK:n kulttuurijärjestö UNESCO ja sen kulttuuriperintöä koskevat sopimukset (esim. Maailmanperintösopimus 1972; Aineettoman kulttuuriperinnön suojelemista koskeva yleissopimus 2003; Yleissopimus kulttuuriomaisuuden luvattoman tuonnin, viennin ja omistusoikeuden siirron kieltämiseksi ja ehkäisemiseksi 1995) ovat vaikuttaneet maailmanlaajuisesti kulttuuriperintötyöhön ja -politiikkaan. Nämä sopimukset ovat tuoneet uusia näkökulmia muun muassa kansainväliseen lainsäädäntöön, turismiin, luonnonsuojelu- ja kulttuuriympäristötoimenpiteisiin sekä ylipäänsä vaikuttaneet ratkaisevasti siihen, miten "historia", "menneisyys", "perinne" ja "perintö" ymmärretään nyky-yhteiskunnissa. 2000-luvulla UNESCO on yhä enenevässä määrin halunnut tuoda esille ruohonjuuritason toimintaa, perinteiden elävyyttä, ihmisten toimijuutta

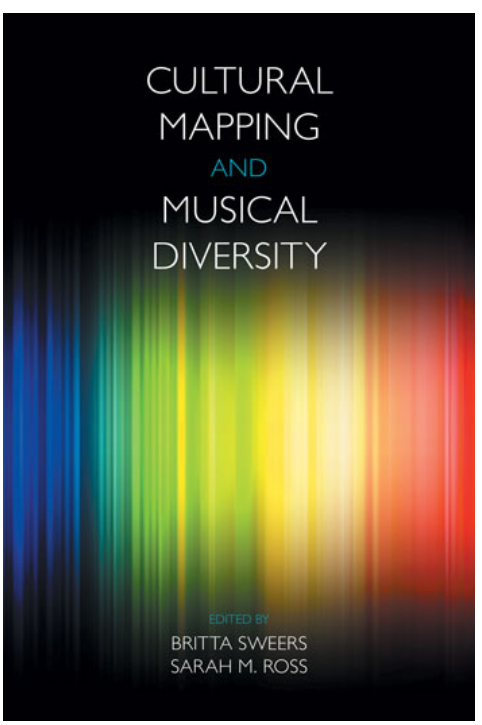
sekä kulttuurisia ja "aineettomia" arvoja, mikä on vaikuttanut myös käytännön kulttuuriperintötyöhön. Paraikaa Suomessa on esimerkiksi käynnissä aineettoman kulttuuriperinnön luettelointiprosessi (Museovirasto 2021), jonka Museovirasto toteuttaa osallistavasti. Näin se pyrkii tuomaan institutionaalisiin kulttuuriperinnön valikointiprosesseihin lisää ääniä suoraan esimerkiksi järjestötyön ja kansalaistoiminnan kentiltä. Tämäntapaisen työn kehittämiseen UNESCO pyrkii ohjaamaan kulttuurisuunnittelun (cultural planning) ja sen alalajin kulttuurikartoituksen (cultural mapping) kaltaisilla käsitteillä, joita on kehitetty kaupunki- ja kulttuuripolitiikkaa tarkastelevissa tutkimussuuntauksissa.

Kulttuurisuunnittelulla tarkoitetaan menetelmää, jossa "kulttuuri" ymmärretään laaja-alaisesti ja jossa ihmisten kulttuurinen pääoma pyritään ottamaan osaksi kaupunkipoliittista päätöksentekoa. Menetelmässä pyritään huomioimaan alueellisia identiteettejä, perinteitä ja muita merkityksenantoja. Kulttuurikartoitus taas on kulttuurinsuunnittelun työvaihe, jonka avulla pyritään lisäämään ymmärrystä alueisiin liittyvästä "hiljaisesta tiedosta", 
perinteistä ja taidoista. Käytännössä kulttuurikartoitusta voidaan tehdä esimerkiksi osallistavilla paikkatietotyökaluilla ja -menetelmillä. (Vahlo 2015; Häyrynen 2015.)

Cultural Mapping and Musical Diversity -artikkelikokoelma on pääosin eurooppalaisten etnomusikologien käytännönläheinen vastaus musiikkiin liittyviin kulttuurisuunnittelu- ja -kartoitusnäkökulmiin, ja toimittajien mukaan kokoelma pyrkii osallistumaan aiheeseen nimenomaan suhteessa UNESCOn ajatuksiin aineettomasta kulttuuriperinnöstä. Artikkelikokoelman fokuksessa ovat musiikkikulttuurit laajasti ymmärrettynä: musiikki ja musiikin tekeminen nähdään kirjoituksissa etnomusikologian tieteenalan paradigman mukaisesti osana ihmisten kulttuurista toimintaa ja ilmaisua, jolla on moniaalle levittyviä henkilökohtaisia, yhteisöllisiä ja poliittisia merkityksiä. Kokoelmassa tarkastellaan eri puolilta maailmaa kotoisin olevien tapausten kautta, miten ymmärtämällä sensitiivisesti erilaisia musiikillisia ilmiöitä ja kulttuureja voidaan samalla edesauttaa kulttuuripoliittista päätöksentekoa ja oikeudenmukaisuutta sekä musiikillista monimuotoisuutta. Osa kirjan artikkeleista käsittelee UNESCOn aineettoman kulttuuriperinnön yleissopimukseen ja sen toimeenpanoon eri puolilla maailmaa liittyviä tapauksia, osa taas tarkastelee yleisesti musiikkikulttuurisia ilmiöitä ilman kytköksiä UNESCO-politiikkaan.

\section{Kartoittamisen kartoittelua}

Kirja on jaettu neljään ylälukuun, joista ensimmäinen käsittelee kulttuurikartoitusta menetelmänä, toinen kulttuurimaisemaa ja musiikkia, kolmas aineettoman kulttuuriperinnön politiikkoja ja neljäs UNESCOn aineettoman kulttuuriperinnön statuksen saaneita tapausesimerkkejä. Kirjan toimittajilla on ollut kova työ saattaa artikkelit keskustelemaan keskenään aiheiden moninaisuuden takia; jokaisen yläluvun alla onkin hieman keinotekoiselta tuntuva lyhyt johdanto-osuus. Artikkelikokoelman laajuus ja monipolvisuus tekee siitä raskaan luettavan. Raskautta lisää myös se, että vaikka kirja pääsääntöisesti käsittelee kulttuurikartoitusta ja aineettoman kulttuuriperinnön prosesseja, osa artikkeleista ei varsinaisesti ota ollenkaan kantaa tähän kehykseen. Lukijalle jää vaikutelma, että kirjaan on sisällytetty kaikki tarjolla olleet artikkelit, mikä ehkä onkin totta, sillä kirjan lukujen mainitaan perustuvan vuonna 2013 pidetyn konferenssin esitelmiin.

Menetelmällisesti kokoelman artikkelit eivät varsinaisesti kehitä kulttuurikartoituksen ajatusta, vaan ennemmin soveltavat sitä erinäisiin musiikillisiin ilmiöihin ja ikään kuin kartoittavat sen toimivuutta tällä alueella. Vaikka kartat sinänsä eivät millään muotoa ole ainoa kulttuurikartoituksen apuväline, on hieman hämmentävää, että niitä on käytetty analyysin apuna vain muutamassa artikkelissa. Myöskään Suomessa kulttuurikartoituksessa sovellettuja osallistavia paikkatietomenetelmiä (esim. Häyrynen 2015) ei ole käytetty ollenkaan. Osin tämä lienee kiinni kirjoittajien taustasta: paikkatietomenetelmät eivät ehkä kuulu kovin monen etnomusikologin työkalupakkiin. Perinteisempiä menetelmiä kuten haastatteluja ja havainnointia kirjoittajat toki ovat käyttäneet runsaasti, ja näillä on myös paikkansa kulttuurikartoituksen piirissä.

Artikkelikokoelman päällimmäiseksi vaikutelmaksi jää sen näkökulmien hajanaisuus: osa kirjoittajista tulee selvästi hyvinkin soveltavan ja käytännönläheisen tutkimusotteen parista, mikä näkyy jonkinlaisena kritiikittömyytenä suhteessa kulttuurikartoituksen tai ylipäänsä kulttuuriperinnön käsitteisiin. Osa taas menee syvemmälle käsitteiden purkamiseen, ja osa artikkeleista pyrkii tarjoamaan konkreettisia ratkaisuja siihen, miten kulttuurista 
monimuotoisuutta ja kulttuuripoliittista vuoropuhelua voitaisiin lisätä. Kulttuurisuunnitteluun ja -kartoittamiseen elimellisesti liittyvä urbaanin käsite sekä alueellisten identiteettien syvällinen pohdinta jäävät yllättäen artikkelikokoelmassa melko vähälle huomiolle lukuun ottamatta teoksen alkuosaa, jossa esimerkiksi Svend Kjeldsen ja Pekka Suutari tuovat esille identiteettien hybridisyyden ja monikielisillä ja -etnisillä alueilla asuvien ihmisten monipuoliset ja joustavat tavat käyttää musiikkia osana kulttuurista merkityksenantoa. Suutarin artikkeli kiinnostanee ylipäänsä Suomen ja lähialueiden folkloristeja, sillä artikkeli käsittelee kieli-identiteettejä Venäjän Karjalassa sekä musiikin roolia kielellisten ja etnisten identiteettien tuottamisessa ja ylläpitämisessä. Artikkeli pohjautuu kenttätöihin ja keskustelee karjalankielisyydestä tehdyn tutkimuksen kanssa, joten se on monelle alan tutkijalle kehykseltään tuttu. Tutkimuslähtöisestä otteesta huolimatta se voi toimia kulttuurisuunnittelun hengessä avauksena arjen monikielisiin käytäntöihin Karjalassa ja osallistua näin kulttuuripoliittisiin keskusteluihin.

\section{Aineettoman kulttuuriperinnön suojelemista ja kritiikkiä}

Oman kulttuuriperintötutkimustaustani takia olin erityisesti kiinnostunut niistä artikkeleista, jotka käsittelevät UNESCOn aineettoman kulttuuriperinnön sopimukseen liittyviä luettelointiprosesseja ja näihin liittyviä käytäntöjä. Esimerkiksi Marzanna Poplawska käsittelee sopimuksen toimeenpanoon liittyviä kulttuuriperintöpolitiikkoja Puolassa, ja Marc-Antoine Camp ja muut taas analysoivat musiikkiperinteiden luettelointia Sveitsissä. Olen tutkinut vastaavia prosesseja Suomessa (esim. Haapoja-Mäkelä 2019 \& 2020), ja on kiinnostavaa nähdä, miten samanlaisten näkökulmien parissa muuallakin painitaan: se, millaisia perinteitä menneisyydestä valikoidaan kulttuuriperintöstatuksen alle, on kiinni monista tekijöistä, kuten intersektionaalisista toimijuuksista, taloudellisista panostuksista ja poliittisista kiistoista. Cultural Mapping -kokoelmassa kuitenkaan niin sanotut kriittisen kulttuuriperintötutkimuksen uusimmat linjat (kuten esimerkiksi affektiivisten käytäntöjen tutkimus, ks. Smith et al. 2018) eivät ole oikeastaan ollenkaan esillä. Tämä on ymmärrettävää kulttuurisuunnittelun ja -kartoituksen näkökulmasta, sillä nämä suuntaukset kuuluvat vahvasti soveltavan tutkimuksen puolelle.

UNESCO-prosessien käsittelyissä lähimmäs kulttuurikartoituksen ideaa ja kulttuuripoliittiseen keskusteluun osallistumista pääsee Thomas Beardslee, jonka artikkeli "Questioning Safeguarding; Heritage and Capabilities at Jemaa el Fnaa Square, Morocco" sekä kritisoi UNESCOa epäonnistumisesta elävien perinteiden suojelussa että ehdottaa vaihtoehtoisia toimintatapoja. Valitettavasti Beardsleen artikkeli on sijoitettu kokoelmassa aivan loppupäähän, vaikka se olisi ansainnut päästä teoksen alkupuolelle. Tutkimalla UNESCO-listalle nimettyä marokkolaista toria Beardslee toteaa, että UNESCO-prosessit jähmettävät käsitystä kulttuurisista ilmiöistä ja epätasa-arvoistavat perinteiden parissa toimivia ihmisiä, sillä prosessien hallinta ja säätely vaativat osaamista ja erityistaitoja ja näin ohjaavat toimintoja institutionaalisiin käsiin. Beardslee ehdottaa tilalle mallia, jonka avulla vahvistetaan perinteiden osaajien pystyvyyttä ja toimijuutta esimerkiksi koulutuksen ja terveydenhuollon alueilla. Tämä malli ei ehkä sellaisenaan olisi sovellettavissa poliittisesti suhteellisen vakaalla Suomen alueella, mutta se voisi tarjota näkökulmia esimerkiksi ruohonjuuritason kulttuuriperintötyöhön täälläkin. 


\section{Lopuksi}

Käsillä oleva artikkelikokoelma on laaja otos eurooppalaisesta etnomusikologiasta ja monista sen tämänhetkisistä kiinnostuksenkohteista, kuten paikallisten musiikkikulttuurien tukemisesta ja inklusiivisista kulttuuripolitiikoista. Teos palvelee kenties parhaiten nimenomaan soveltavan etnomusikologian tai kulttuuriperintötyön ammattilaisia artikkelien käytännönläheisen otteen vuoksi: se voi tarjota mainion vertailevan näkökulman esimerkiksi UNESCO-prosessien, turismialan ja perinnemusiikkien parissa työskenteleville. Tutkimuspuolella teos voi hyödyttää esimerkiksi kulttuurikartoituksesta ja -suunnittelusta kiinnostuneita opinnäytteiden tekijöitä, jotka kaipaavat kansainvälisiä vertailukohtia ja malleja kulttuurikartoituksen toteuttamiseen.

Kiinnostavaa onkin nähdä, tuleeko kulttuurikartoituksen kaltaisista käsitteistä paljon hyödynnettyjä menetelmiä tulevaisuuden kulttuuriperintötyössä ja (humanistisessa) kaupunkitutkimuksessa myös Suomessa. Nämä menetelmät ovat selvästi tuloillaan (ks. Häyrynen \& Wallin 2017; Vahtikari ym. 2021), ja ne saattavat hyvinkin olla merkityksellisiä työkaluja erityisesti yhteiskunta- ja työelämäsuuntautuneessa humanistisessa tutkimuksessa.

\section{Kirjallisuus}

Haapoja-Mäkelä, Heidi. 2019. Näkymiä suomalaiseen muinaisuuteen: Aineeton kulttuuriperintö, kalevalaisuus, paikka ja maisema. Terra 131(2), 97-112. https://terra.journal.fi/article/view/77644/44693

Haapoja-Mäkelä, Heidi. 2020. Elävät perintömme: Kansallinen me aineettoman kulttuuriperinnön luetteloinnissa. Suomen Museo - Finskt Museum 2020, 49-66.

Häyrynen, Maunu. 2015. Cultural Planning in the Eastern Pori Suburbs: Applicability of the Approach? Culture and Local Governance / Culture et gouvernance locale 5(1-2), 101-116.

Häyrynen, Maunu ja Wallin, Antti (toim.). 2017. Kulttuurisuunnittelu - Kaupunkikehittämisen uusi näkökulma. Tietolipas 258. Helsinki: Suomalaisen Kirjallisuuden Seura.

Smith, Laurajane, Margaret Wetherell ja Gary Campbell. 2018. Emotion, Affective Practices, and the Past in the Present. London: Routledge.

Vahlo, Jukka. 2015. Kulttuurisuunnittelua tulevaisuuden kulttuuripääkaupungeissa? Vertailussa Turku 2011 toiminnan ja kulttuurisuunnittelutoimintamallin yhteydet. Yhdyskuntasuunnittelu 52(2). http://www.yss.fi/journal/kulttuurisuunnittelua-tulevaisuuden/

Vahtikari, Tanja, Terhi Ainiala, Aura Kivilaakso, Pia Olsson ja Panu Savolainen (toim.). 2021. Humanistinen kaupunkitutkimus. Tampere: Vastapaino.

Filosofian tohtori ja musiikin maisteri Heidi Henriikka Mäkelä (ent. Haapoja-Mäkelä) toimii post doc -tutkijana Helsingin yliopistossa Koneen säätiön rahoittamissa hankkeissa "Omistajuus, kieli kulttuuriperintö" sekä "Materiality, Verbal Art, Mythic Knowledge and the Lived Environment". 